\title{
INHALT
}

Band I

Einleitung

Die griechische Tragödie:

Kult und Politik, Wort und

Musik 3

Euripides: Leben und

Werk 5

Themen der euripideischen

Tragödien 7

Frauen in der euripideischen

Tragödie 8

Mythos und Tragödie:

Annäherungen an Elektra 13

Politik und Tragödie 21

Theologie und

Dramaturgie 26

Rezeptionslinien 29

Zur Übersetzung und

zum Übersetzer 37
Alkestis 40
Medeia $\mathbf{1 3 6}$
Hippolytos 250
Elektra 368
Herakles 480 


\section{Band II}

Die Troerinnen 600

Iphigenie im Lande der

Taurer 712

Helena 838

Orestes 976

Die Bakchen 1116

Anhang

Anmerkungen 1235

Weiterführende Literatur 1318 
DIE TROERINNEN 